Open Subjects 
Edinburgh Critical Studies in Renaissance Culture

Series Editor: Lorna Hutson

Titles available in the series:

Open Subjects: English Renaissance Republicans, Modern Selfhoods and the Virtue of Vulnerability

James Kuzner

$9780748642533 \mathrm{Hbk}$

The Phantom of Chance: From Fortune to Randomness in SeventeenthCentury French Literature

John D. Lyons

$9780748645152 \mathrm{Hbk}$

Visit the Edinburgh Critical Studies in Renaissance Culture website at www.euppublishing.com/series/ecsrc 


\section{Open Subjects}

English Renaissance Republicans, Modern Selfhoods, and the Virtue of Vulnerability

James Kuzner

Edinburgh University Press 
(C) James Kuzner, 2011

Edinburgh University Press Ltd

22 George Square, Edinburgh

www.euppublishing.com

Typeset in 10.5/13 Adobe Sabon

by Servis Filmsetting Ltd, Stockport, Cheshire, and printed and bound in Great Britain by

CPI Antony Rowe, Chippenham and Eastbourne

A CIP record for this book is available from the British Library

ISBN 9780748642533 (hardback)

The right of James Kuzner

to be identified as author of this work

has been asserted in accordance with

the Copyright, Designs and Patents Act 1988. 